\title{
SEIPR-Mathematical Model of the Pneumonia Spreading in Toddlers with Immunization and Treatment Effects
}

\section{Model Matematika SEIPR Penyebaran Penyakit Pneumonia pada Balita dengan Faktor Imunisasi dan Pengobatan}

\author{
Rusniwati S. Imran ${ }^{1^{*}}$, Resmawan ${ }^{2^{*}}$, Novianita Achmad ${ }^{3 *}$, Agusyarif Rezka Nuha ${ }^{4^{*}}$
}

\begin{abstract}
This research discussed the SEIPR mathematical model on the spread of pneumonia among children under five years old. The development of the model was done by considering factors of immunization and treatment factors, in an effort to reduce the rate of spread of pneumonia. In this research, mathematical model construction, stability analysis, and numerical simulation were carried out to see the dynamics of pneumonia cases in the population. The model analysis produces two equilibrium points, which are the equilibrium point without the disease, the endemic equilibrium point, and the basic reproduction number $\left(R_{0}\right)$ as the threshold value for disease spread. The point of equilibrium without disease reaches a stable state at the moment $R_{0}<1$, which indicates that pneumonia will disappear from the population, while the endemic equilibrium point reaches a stable state at that time $R_{0}>1$, which indicates that the disease will spread in the population. Furthermore, numerical simulations show that increasing the rate parameters of infected individuals undergoing treatment $(\omega)$, the treatment success rate $(q)$, and the immunization proportion $(\theta)$, could suppress the basic reproductive number so that control of the disease spread rate can be accelerated.
\end{abstract}

Keywords: Pneumonia, SEIPR-Mathematical Model, Equilibrium Point, Basic Reproduction Number.

\begin{abstract}
Abstrak
Penelitian ini membahas model matematika SEIPR pada penyebaran penyakit pneumonia pada balita. Pengembangan model dilakukan dengan mempertimbangkan faktor imunisasi dan pengobatan, sebagai upaya untuk menekan laju penyebaran penyakit pneumonia. Pada penelitian ini dilakukan konstruksi model matematika, analisis stabilitas, dan simulasi numerik untuk melihat dinamika kasus pneumonia pada populasi. Analisis model menghasilkan dua titik kesetimbangan yaitu titik kesetimbangan tanpa penyakit, titik kesetimbangan endemik, dan bilangan reproduksi dasar $\left(R_{0}\right)$ sebagai nilai ambang batas
\end{abstract}

*Program Studi Matematika, Jurusan Matematika FMIPA Universitas Negeri Gorontalo Email: ${ }^{1}$ unimran01@gmail.com, ${ }^{2 *}$ resmawan@ung.ac.id, ${ }^{3}$ achmadnovianita@gmail.com, 4agusyarif@ung.ac.id

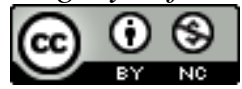

This work is licensed under a Creative Commons Attribution-NonCommercial 4.0 International License 


\section{Rusniwati S. Imran, Resmawan, Novianita Achmad, Agusyarif Rezka Nuha Jurnal Matematika, Statistika E Komputasi}

terjadinya penyebaran penyakit. Titik kesetimbangan tanpa penyakit mencapai kondisi stabil pada saat $R_{0}<1$, yang menunjukkan bahwa penyakit pneumonia akan menghilang dari populasi, sedangkan titik kesetimbangan endemik mencapai kondisi stabil pada saat $R_{0}>1$, yang menunjukkan bahwa penyakit akan menyebar dalam populasi. Selanjutnya, simulasi numerik menunjukkan bahwa peningkatan parameter laju individu terinfeksi yang menjalani pengobatan $(\omega)$, tingkat keberhasilan pengobatan $(q)$, dan proporsi imunisasi $(\theta)$, dapat menekan angka bilangan reproduksi dasar, sehingga pengendalian laju penyebaran penyakit dapat dipercepat.

Kata kunci: Pneumonia, Model Matematika SEIPR, Titik Kesetimbangan, Bilangan, Reproduksi Dasar

\section{Pendahuluan}

Pemodelan matematika merupakan salah satu cara untuk merepresentasikan permasalahan yang terjadi di dunia nyata ke dalam bentuk matematika berupa persamaan atau sistem persamaan [10]. Pemodelan matematika dapat diterapkan dalam berbagai bidang ilmu pengetahuan diantaranya biologi, ekonomi, kesehatan atau lainnya. Pemodelan matematika juga dapat menggambarkan fenomena penyebaran suatu penyakit. Salah satu fenomena penyebaran penyakit yang dapat dikaji melalui pendekatan model matematika yaitu tentang penyebaran penyakit pneumonia.

Menurut badan kesehatan dunia atau World Health Organization (WHO), pneumonia adalah salah satu infeksi saluran pernapasan akut (ISPA) yang menyerang paru-paru yang disebabkan oleh berbagai mikroorganisme seperti virus, jamur dan bakteri, sehingga paru-paru akan terisi oleh cairan yang dapat menyulitkan seseorang bernafas. Pneumonia sering terjadi pada bayi di bawah usia lima tahun (balita) dan menjadi penyebab tertinggi kematian dari 2 juta anak setiap tahun [20]. Penderita pneumonia di indonesia pada tahun 2017 berjumlah 447.431. Prevalensi pneumonia tahun $2013(1,6 \%)$ naik menjadi $(2 \%)$ dari populasi balita yang ada di Indonesia pada tahun 2018 [7, 16].

Penggunaan model matematika dalam upaya penanganan penyakit pneumonia telah banyak dilakukan sebelumnya. Jacob [6] meneliti model penyebaran penyakit pneumonia dengan asumsi bahwa penyakit pneumonia bisa disebabkan karena bawaan sejak lahir sehingga penelitian ini memperhatikan faktor carries (faktor bawaan). Selanjutnya Rahmawati [13] melakukan pengembangan dengan menambahkan asumsi bahwa individu yang sembuh akan kembali menjadi rentan setelah 2 tahun yang disebabkan karena hilangnya kekebalan tubuh. Penelitian lain dilakukan oleh Fajar [4] dengan memperhatikan faktor host yaitu kondisi imun lemah dan vaksinasi sebagai faktor pengendali penyakit pneumonia. Beberapa penelitian lain yang membahas masalah pneumonia dalam perspektif pemodelan dapat dilihat pada $[9,11,12]$.

Pada penelitian ini, model matematika penyebaran penyakit pneumonia dari Fajar [4] dimodifikasi dengan menambahkan kelas exposed (E) yakni individu terinfeksi tetapi belum menunjukkan gejala klinis dan belum dapat menularkan penyakit [2], selanjutnya menambahkan faktor pengobatan bagi individu yang terinfeksi karena penderita pneumonia diberikan pengobatan dengan obat antibiotik [17], dan memperhatikan faktor imunisasi yang diberikan pada setiap individu yang lahir agar terhindar dari penyakit pneumonia [2], serta memperhatikan faktor bawaan yakni balita yang memiliki penyakit paru-paru bawaan dari orang tuanya. Penyakit paruparu bawaan menjadi salah satu faktor resiko terjadinya pneumonia pada balita [8]. Kemudian dibentuk sistem persamaan diferensial untuk penyebaran penyakit pneumonia dengan faktor imunisasi dan pengobatan, selanjutnya dilihat perilaku solusi dari titik kesetimbangan agar dapat 


\section{Rusniwati S. Imran, Resmawan, Novianita Achmad, Agusyarif Rezka Nuha Jurnal Matematika, Statistika E Komputasi}

dianalisa kestabilan dari titik kesetimbangan tersebut, dan melakukan simulasi numerik untuk melihat dinamika penyebaran penyakit pneumonia.

\section{Model Matematika}

Dalam artikel ini, beberapa asumsi yang akan digunakan adalah sebagai berikut:

1. Model matematika terbentuk dari lima populasi yang saling berinteraksi yaitu populasi Susceptible adalah individu sehat tetapi rentan terhadap penyakit pneumonia yang dinotasikan dengan S, populasi Exposed adalah individu laten atau terpapar penyakit pneumonia yang dinotasikan dengan $\mathrm{E}$, populasi Infected adalah individu terinfeksi penyakit pneumonia yang dinotasikan dengan I, dan populasi Pengobatan adalah individu terinfeksi yang diberi pengobatan yang dinotasikan dengan $\mathrm{P}$, dan populasi yang Recovery adalah populasi yang sembuh yang dinotasikan dengan $\mathrm{R}$.

2. Populasi bersifat tertutup, artinya penambahan atau pengurangan populasi hanya dikarenakan oleh kelahiran dan kematian.

3. Setiap individu yang lahir yang tidak mendapatkan imunisasi akan rentan terhadap penyakit pneumonia.

4. Imunisasi yang diberikan efektif dan berhasil, sehingga membuat individu yang mendapatkan imunisasi berpindah ke populasi Recovery $(\mathrm{R})$.

5. Penyakit dapat menyebabkan kematian.

6. Setiap populasi terdapat kematian alami sebesar $\mu$

7. Adanya interaksi antara individu rentan dan individu terinfeksi sehingga menyebabkan individu dalam kompartemen (Susceptible) berpindah ke kelas E (Exposed).

8. Pada saat individu laten (E) mengalami penurunan daya tahan tubuh maka akan membuat virus pneumonia menjadi aktif sehingga menjadi individu yang terinfeksi.

9. individu rentan yang memiliki penyakit paru-paru bawaan ketika berinteraksi dengan individu terinfeksi maka akan aktif terinfeksi penyakit pneumonia. Populasi terinfeksi yang menjalani pengobatan sebesar $\omega$.

Berdasarkan asumsi tersebut diperoleh diagram kompartemen yang ditunjukkan pada Gambar 1

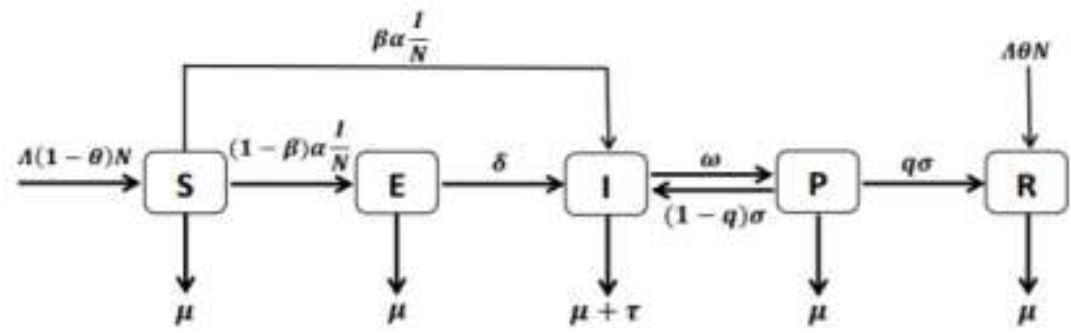

Gambar 1. Skema Populasi Model SEIPR untuk Penyebaran Penyakit Pneumonia

Berdasarkan diagram kompartemen pada Gambar 1, diperoleh sistem persamaan diferensial berikut, 


\section{Rusniwati S. Imran, Resmawan, Novianita Achmad, Agusyarif Rezka Nuha Jurnal Matematika, Statistika E Komputasi}

$$
\begin{aligned}
& \frac{d S}{d t}=\Lambda(1-\theta) N-\alpha \frac{I}{N} S-\mu S \\
& \frac{d E}{d t}=(1-\beta) \alpha \frac{I}{N} S-(\delta+\mu) E \\
& \frac{d I}{d t}=\beta \alpha \frac{I}{N} S+\delta E-(\omega+\tau+\mu) I+(1-q) \sigma P \\
& \frac{d P}{d t}=\omega I-(\sigma+\mu) P \\
& \frac{d R}{d t}=q \sigma P+\Lambda \theta N-\mu R
\end{aligned}
$$

Selanjutnya dilakukan penskalaan untuk memudahkan proses analisis model. Dengan mendefinisikan variabel-variabel baru yang didefinisikan pada persamaan berikut : $s=\frac{S}{N}, e=$ $\frac{E}{N}, i=\frac{I}{N}, p=\frac{P}{N}, r=\frac{R}{N}$, sistem persamaan diatas menjadi,

\begin{tabular}{|c|c|}
\hline$\Lambda$ & Laju kelahiran \\
\hline$\mu$ & Laju kematian alami \\
\hline$\tau$ & Laju kematian karena penyakit \\
\hline$\alpha$ & $\begin{array}{l}\text { Laju penularan penyakit akibat adanya kontak } \\
\text { antara populasi terinfeksi dengan populasi rentan }\end{array}$ \\
\hline$\delta$ & Laju individu laten menjadi individu yang aktif terinfeksi \\
\hline$\beta$ & $\begin{array}{l}\text { Proporsi individu rentan yang memiliki } \\
\text { penyakit paru-paru bawaan sejak lahir }(0<\beta<1)\end{array}$ \\
\hline$\theta$ & Proporsi imunisasi $(0<\theta<1)$ \\
\hline$\omega$ & Laju individu terinfeksi yang menjalani pengobatan \\
\hline$q$ & Proporsi individu kelas pengobatan sembuh $(0<q<1)$ \\
\hline$\sigma$ & Peluang individu sembuh dengan pengobatan \\
\hline
\end{tabular}

$$
\begin{aligned}
& \frac{d s}{d t}=\Lambda(1-\theta)-\alpha i s-\mu s \\
& \frac{d e}{d t}=(1-\beta) \alpha i s-(\delta+\mu) e \\
& \frac{d i}{d t}=\beta \alpha i s+\delta e-(\omega+\tau+\mu) i+(1-q) \sigma p \\
& \frac{d p}{d t}=\omega i-(\sigma+\mu) p \\
& \frac{d r}{d t}=q \sigma p+\Lambda \theta-\mu r
\end{aligned}
$$

Adapun parameter-parameter yang digunakan pada persamaan (2) disajikan pada Tabel 1

Tabel 1. Keterangan Parameter Model 


\section{Rusniwati S. Imran, Resmawan, Novianita Achmad, Agusyarif Rezka Nuha Jurnal Matematika, Statistika E Komputasi}

\section{Hasil dan Pembahasan}

\subsection{Titik Kesetimbangan}

Untuk menentukan titik kesetimbangan pada sistem persamaan (2), dapat dicari dengan menyelesaikan persamaan tersebut dengan $\frac{d s}{d t}=\frac{d e}{d t}=\frac{d i}{d t}=\frac{d p}{d t}=\frac{d r}{d t}=0$.Dari penyelesaian persamaan tersebut diperoleh dua titik kesetimbangan sebagai berikut :

1. Titik Kesetimbangan Tanpa Penyakit Pneumonia $\left(E_{0}\right)$

2. Titik Kesetimbangan Endemik $\left(E_{1}\right)$

$$
E_{0}(s, e, i, p, r)=\left(\frac{\Lambda(1-\theta)}{\mu}, 0,0,0, \frac{\Lambda \theta}{\mu}\right)
$$

dengan

$$
E_{1}(s, e, i, p, r)=\left(s^{*}, e^{*}, i^{*}, p^{*}, r^{*}\right)
$$

$$
\begin{aligned}
& s^{*}=\frac{(\delta+\mu)((\mu+\sigma)(\mu+\tau)+(\mu+q \sigma) \omega)}{\alpha(\delta+\beta \mu)(\mu+\sigma)} \\
& e^{*}=\frac{(-1+\beta)(\Lambda \alpha(-1+\theta)(\delta+\beta \mu)(\mu+\sigma)+\mu(\delta+\mu)((\mu+\sigma)(\mu+\tau)+(\mu+q \sigma) \omega)}{\alpha(\delta+\mu)(\delta+\beta \mu)(\mu+\sigma)} \\
& i^{*}=-\frac{\mu}{\alpha}-\frac{\Lambda(-1+\theta)(\delta+\beta \mu)(\mu+\sigma)}{(\delta+\mu)((\mu+\sigma)(\mu+\tau)+(\mu+q \sigma) \omega)} \\
& p^{*}=-\frac{\mu \omega}{\alpha(\mu+\sigma)}-\frac{\Lambda(-1+\theta)(\delta+\beta \mu) \omega}{(\delta+\mu)((\mu+\sigma)(\mu+\tau)+(\mu+q \sigma) \omega)} \\
& r^{*}=-\frac{q \sigma \omega}{\alpha(\mu+\sigma)}+\frac{\Lambda \theta(\delta+\mu)(\mu+\sigma)(\mu+\tau)+\Lambda(\theta \mu(\delta+\mu)+q(\delta+(\beta+\theta-\beta \theta) \mu) \sigma) \omega}{\mu(\delta+\mu)((\mu+\sigma)(\mu+\tau)+(\mu+q \sigma) \omega)}
\end{aligned}
$$

\subsection{Bilangan Reproduksi Dasar $\left(\boldsymbol{R}_{0}\right)$}

Tingkat penyebaran suatu penyakit menular dalam suatu wilayah dapat ditunjukkan oleh nilai bilangan reproduksi dasar $\left(R_{0}\right)$ [3]. Bilangan reproduksi dasar diperoleh dengan menggunakan metode matriks next generation. Penggunaan metode ini secara spesik dapat dilihat pada $[14,15]$. Matriks next generation dapat diperoleh dari kelas populasi terinfeksi pada sistem persamaan (2). Sehingga kelas populasi terinfeksi dapat ditulis sebagai berikut:

$$
\begin{aligned}
& \frac{d e}{d t}=(1-\beta) \alpha i s-(\delta+\mu) e \\
& \frac{d i}{d t}=\beta \alpha i s+\delta e-(\omega+\tau+\mu) i+(1-q) \sigma p \\
& \frac{d p}{d t}=\omega i-(\sigma+\mu) p
\end{aligned}
$$

Berdasarkan persamaan (3) diperoleh matriks $\mathrm{F}$ dan $\mathrm{V}$ sebagai berikut

$$
F=\left[\begin{array}{ccc}
0 & (1-\beta) \alpha S & 0 \\
0 & \beta \alpha S & 0 \\
0 & 0 & 0
\end{array}\right], V=\left[\begin{array}{ccc}
(\delta+\mu) & 0 & 0 \\
-\delta & \omega+\tau+\mu & -(1-q) \sigma \\
0 & -\omega & \sigma+\mu
\end{array}\right]
$$

Selanjutnya dilakukan subtitusi titik kesetimbangan tanpa penyakit pneumonia yakni $E_{0}(s, e, i, p, r)=\left(\frac{\Lambda(1-\theta)}{\mu}, 0,0,0, \frac{\Lambda \theta}{\mu}\right)$ pada persamaan (3), sehingga diperoleh: 


\section{Rusniwati S. Imran, Resmawan, Novianita Achmad, Agusyarif Rezka Nuha Jurnal Matematika, Statistika E Komputasi}

$$
F=\left[\begin{array}{ccc}
0 & \frac{\alpha(1-\beta)(\Lambda(1-\theta))}{\mu} & 0 \\
0 & \frac{\beta \alpha(\Lambda(1-\theta))}{\mu} & 0 \\
0 & 0 & 0
\end{array}\right], V=\left[\begin{array}{ccc}
(\delta+\mu) & 0 & 0 \\
-\delta & \omega+\tau+\mu & -(1-q) \sigma \\
0 & -\omega & \sigma+\mu
\end{array}\right]
$$

Berdasarkan [18] bilangan reproduksi dasar $R_{0}$ merupakan radius spektral dari matriks $\mathrm{K}$, dengan $K=F V^{-1}$. Sehingga diperoleh $R_{0}$ sebagai berikut:

$$
R_{0}=\frac{\Lambda \alpha(1-\theta)(\delta+\beta \mu)(\mu+\sigma)}{\mu(\delta+\mu)((\mu+\sigma)(\mu+\tau)+(\mu+q \sigma) \omega)}
$$

Persamaan (5) adalah nilai ambang batas yang menjadi tolak ukur tingkat penyebaran populasi terinfeksi. Kondisi yang memungkinkan berdasarkan [3] terdapat pada Definisi (3.1) sebagai berikut.

Definisi 3.1 Jika $R_{0}<1$ titik kesetimbangan tanpa penyakit stabil asimtotik lokal, sehingga tidak terjadi penyebaran penyakit. Selanjutnya jika $R_{0}>1$ titik kesetimbangan endemik stabil asimtotik lokal, sehingga terjadi penyebaran penyakit pneumonia.

\subsection{Analisis Kestabilan Titik Kesetimbangan}

Model penyebaran penyakit pneumonia diatas merupakan sistem persamaan diferensial nonlinear [1]. Analisis kestabilan untuk sistem persamaan diferensial non-linear dilakukan dengan teknik pelinearan yang menggunakan matriks Jacobian [19]. Berdasarkan persamaan (2) maka diperoleh matriks jacobian sebagai berikut:

$$
J=\left[\begin{array}{ccccc}
-\alpha i-\mu & 0 & -\alpha s & 0 & 0 \\
\alpha i(1-\beta) & -\delta-\mu & \alpha s(1-\beta) & 0 & 0 \\
\beta \alpha i & \delta & \beta \alpha i s-\omega-\tau-\mu & (1-q) \sigma & 0 \\
0 & 0 & \omega & -\sigma-\mu & 0 \\
0 & 0 & 0 & q \mu & -\mu
\end{array}\right]
$$

\subsubsection{Analisis Kestabilan Titik Kesetimbangan Tanpa Penyakit}

Selanjutnya, Untuk memperoleh kestabilan sistem dititik kesetimbangan tanpa penyakit, substitusi titik kesetimbangan $E_{0}$ pada matriks jacobi (6), sehingga diperoleh :

dengan

$$
J=\left[\begin{array}{ccccc}
A_{11} & 0 & A_{13} & 0 & 0 \\
0 & A_{22} & A_{23} & 0 & 0 \\
0 & A_{32} & A_{33} & A_{34} & 0 \\
0 & 0 & A_{43} & A_{44} & 0 \\
0 & 0 & 0 & A_{54} & A_{55}
\end{array}\right]
$$

$$
\begin{array}{ll}
A_{11}=-\mu<0 & A_{34}=(1-q) \sigma>0 \\
A_{13}=-\frac{\alpha \Lambda(1-\theta)}{\mu}<0 & A_{43}=\omega>0 \\
A_{22}=-\delta-\mu<0 & A_{44}=-\sigma-\mu<0 \\
A_{23}=\frac{\alpha(1-\beta)(\Lambda(1-\theta))}{\mu}>0 & A_{54}=q \sigma>0 \\
A_{32}=\delta>0 & A_{55}=-\mu<0
\end{array}
$$




\section{Rusniwati S. Imran, Resmawan, Novianita Achmad, Agusyarif Rezka Nuha Jurnal Matematika, Statistika E Komputasi}

$$
A_{25}=\frac{\beta \alpha(\Lambda(1-\theta))}{\mu}-(\omega+\tau+\mu)
$$

Langkah selanjutnya yaitu mencari persamaan karakteristik diperoleh dari $\operatorname{det}\left(\lambda I-J\left(E_{0}\right)\right)=0$, sehingga diperoleh

$$
\begin{gathered}
\left(A_{11}-\lambda\right)\left(-A_{55}+\lambda\right)\left(A_{23} A_{32}\left(A_{44}-\lambda\right)+\left(A_{22}-\lambda\right)\left(A_{34} A_{43}+\left(A_{33}-\lambda\right)\left(-A_{44}+\lambda\right)\right)\right) \\
=0
\end{gathered}
$$

Berdasarkan persamaan (8) diperoleh lima nilai eigen. Dua nilai eigen diantaranya adalah

$$
\begin{aligned}
& \lambda_{1}=A_{11}=-\mu \\
& \lambda_{2}=A_{55}=-\mu
\end{aligned}
$$

Karena semua paramater bernilai positif maka $\lambda_{1}<0, \lambda_{2}<0$, dan untuk ketiga nilai eigen lainnya diperoleh dengan menyelesaikan persamaaan kubik berikut

dengan :

$$
\lambda^{3}-a_{1} \lambda^{2}-a_{2} \lambda+a_{3}=0
$$

$$
\begin{aligned}
& a_{0}=1 \\
& a_{1}=-A_{22}-A_{33}-A_{44} \\
& a_{2}=\left(3 \mu^{2}+2 \mu(\sigma+\tau+\omega)+\delta(2 \mu+\sigma+\tau+\omega)+\sigma(\tau+q \omega)-\frac{\Lambda \alpha(1-\theta)(\delta+\beta \mu)(\mu+\sigma)}{\mu}\right. \\
& a_{3}=((\delta+\mu)(\mu+\sigma)(\mu+\tau)+(\mu+q \sigma) \omega)-\frac{\Lambda \alpha(1-\theta)(\delta+\beta \mu)(\mu+\sigma)}{\mu}
\end{aligned}
$$

Akar-akar persamaan (9) merupakan nilai-nilai eigen lain dari persamaan karakteristik (8) yaitu $\lambda_{3}, \lambda_{4}, \lambda_{5}$. Berdasarkan sifat akar persamaan kubik, diperoleh sistem persamaan berikut.

i. Tinjau $\mathrm{a}_{1}$

$$
\begin{gathered}
\lambda_{3}+\lambda_{4}+\lambda_{5}=-a_{1} \\
\lambda_{3} \lambda_{4}+\lambda_{3} \lambda_{5}+\lambda_{4} \lambda_{5}=a_{2} \\
\lambda_{3} \lambda_{4} \lambda_{5}=-a_{3}
\end{gathered}
$$

$a_{1}=-A_{22}-A_{33}-A_{44}$

Berdasarkan persamaan (5), $R_{0}<1$ mengakibatkan

$$
\begin{aligned}
& \frac{\Lambda \alpha(1-\theta)(\delta+\beta \mu)(\mu+\sigma)}{\mu(\delta+\mu)((\mu+\sigma)(\mu+\tau)+(\mu+q \sigma) \omega)}<1 \\
& \frac{\Lambda \alpha(1-\theta)(\delta+\beta \mu)(\mu+\sigma)}{\mu}<(\delta+\mu)((\mu+\sigma)(\mu+\tau)+(\mu+q \sigma) \omega)
\end{aligned}
$$

Karena $0<q<1$, maka

$$
\begin{aligned}
& \frac{\Lambda \alpha(1-\theta)(\delta+\beta \mu)(\mu+\sigma)}{\mu}<(\delta+\mu)((\mu+\sigma)(\mu+\tau)+(\mu+\sigma) \omega) \\
& \frac{\Lambda \alpha(1-\theta)(\delta+\beta \mu)(\mu+\sigma)}{\mu}<(\delta+\mu)(\mu+\sigma)(\mu+\tau+\omega) \\
& \frac{\Lambda \alpha(1-\theta)(\delta+\beta \mu)}{\mu}<(\delta+\mu)(\mu+\tau+\omega)
\end{aligned}
$$

Karena $0<\beta<1$, maka

$$
\frac{\Lambda \alpha(1-\theta)(\delta \beta+\beta \mu)}{\mu}<\frac{\Lambda \alpha(1-\theta)(\delta+\beta \mu)}{\mu}<(\delta+\mu)(\mu+\tau+\omega)
$$




\section{Rusniwati S. Imran, Resmawan, Novianita Achmad, Agusyarif Rezka Nuha Jurnal Matematika, Statistika E Komputasi}

$$
\begin{aligned}
& \frac{\Lambda \alpha(1-\theta)(\delta \beta+\beta \mu)}{\mu}<(\delta+\mu)(\mu+\tau+\omega) \\
& \frac{\Lambda \alpha(1-\theta)(\beta(\delta+\mu))}{\mu}<(\delta+\mu)(\mu+\tau+\omega) \\
& \frac{\Lambda \alpha(1-\theta) \beta}{\mu}<(\mu+\tau+\omega) \\
& \frac{\Lambda \alpha(1-\theta) \beta}{\mu}-(\mu+\tau+\omega)<0 \\
& A_{33}<0
\end{aligned}
$$

Karena $A_{22}<0, A_{44}<0$, dan $A_{33}<0$, mengakibatkan $a_{1}>0$, maka jumlah dari ketiga nilai eigen tersebut bernilai negatif $\left(\lambda_{3}+\lambda_{4}+\lambda_{5}<0\right)$. Hal ini menandakan di antara ketiga nilai eigen tersebut, selalu ada yang bernilai negatif, anggap $\lambda_{3}<0$. Selanjutnya untuk memeriksa kestabilan titik kesetimbangan cukup dengan memperhatikan $\lambda_{4}$ dan $\lambda_{5}$. Jika $\lambda_{4}<0$ dan $\lambda_{5}<0$, maka titik kesetimbangan tanpa penyakit akan stabil, sedangkan jika $\lambda_{4}>0$ dan $\lambda_{5}>0$, maka titik kesetimbangan tidak stabil.

ii. Tinjau $a_{2}$

Berdasarkan persamaan (5), $R_{0}<1$ mengakibatkan

$$
\begin{aligned}
& \frac{\Lambda \alpha(1-\theta)(\delta+\beta \mu)(\mu+\sigma)}{\mu(\delta+\mu)((\mu+\sigma)(\mu+\tau)+(\mu+q \sigma) \omega)}<1 \\
& \frac{\Lambda \alpha(1-\theta)(\delta+\beta \mu)(\mu+\sigma)}{\mu(\delta+\mu)}<((\mu+\sigma)(\mu+\tau)+(\mu+q \sigma) \omega)
\end{aligned}
$$

$$
\begin{aligned}
& \begin{array}{l}
\text { Karena } 0<q<1 \text {, maka } \\
\Lambda \alpha(1-\theta)(\delta+\beta \mu)(\mu+\sigma) \\
\frac{\mu(\delta+\mu)}{\Lambda \alpha(1-\theta)(\delta+\beta \mu)(\mu+\sigma)}
\end{array}<((\mu+\sigma)(\mu+\tau)+(\mu+\sigma) \omega) \\
& \frac{\Lambda(\delta+\mu)}{\Lambda \alpha(1-\theta)(\delta+\beta \mu)} \\
& \frac{\Lambda(\delta+\mu)}{\mu(\mu+\sigma)(\mu+\tau+\omega)} \\
& \frac{\Lambda \alpha(1-\theta)(\delta+\beta(2 \mu+\sigma))}{\mu(\delta+\mu)}<(2 \mu+\sigma+\tau+\omega) \\
& \frac{\Lambda \alpha(1-\theta)(\delta+\beta(2 \mu+\sigma))}{\mu}<(\delta+\mu)(2 \mu+\sigma+\tau+\omega) \\
& \frac{\Lambda \alpha(1-\theta)(\delta+\beta(2 \mu+\sigma))}{\mu}<(\delta(2 \mu+\sigma+\tau+\omega)+\mu(2 \mu+\sigma+\tau+\omega)) \\
& \frac{\Lambda \alpha(1-\theta)(\delta+\beta(2 \mu+\sigma))}{\mu}<\left(\delta(2 \mu+\sigma+\tau+\omega)+\mu(\sigma+\tau+\omega)+2 \mu^{2}\right) \\
& \frac{\Lambda \alpha(1-\theta)(\delta+\beta(2 \mu+\sigma))}{\mu}<\left(\delta(2 \mu+\sigma+\tau+\omega)+2 \mu(\sigma+\tau+\omega)+3 \mu^{2}+\sigma(\tau+q \omega)\right. \\
& \left(2 \mu(\sigma+\tau+\omega)+\delta(2 \mu+\sigma+\tau+\omega)+3 \mu^{2}+\sigma(\tau+q \omega)-\frac{\Lambda \alpha(1-\theta)(\delta+\beta(2 \mu+\sigma))}{\mu}>0\right. \\
& a_{2}>0 \quad
\end{aligned}
$$

iii. Tinjau $a_{3}$ 


\section{Rusniwati S. Imran, Resmawan, Novianita Achmad, Agusyarif Rezka Nuha Jurnal Matematika, Statistika E Komputasi}

Berdasarkan persamaan (5), $R_{0}<1$ mengakibatkan

$$
\begin{aligned}
& \frac{\Lambda \alpha(1-\theta)(\delta+\beta \mu)(\mu+\sigma)}{\mu(\delta+\mu)((\mu+\sigma)(\mu+\tau)+(\mu+q \sigma) \omega)}<1 \\
& \frac{\Lambda \alpha(1-\theta)(\delta+\beta \mu)(\mu+\sigma)}{\mu}<(\delta+\mu)((\mu+\sigma)(\mu+\tau)+(\mu+q \sigma) \omega) \\
& (\delta+\mu)((\mu+\sigma)(\mu+\tau)+(\mu+q \sigma) \omega)-\frac{\Lambda \alpha(1-\theta)(\delta+\beta \mu)(\mu+\sigma)}{\mu}>0 \\
& a_{3}>0
\end{aligned}
$$

Karena $a_{2}>0$ dan $a_{3}>0$, maka nilai dari persamaan kedua dan ketiga dari persamaan (10) memenuhi kondisi berikut

$$
\begin{gathered}
\lambda_{3}\left(\lambda_{4}+\lambda_{5}\right)+\lambda_{4} \lambda_{5}>0 \\
\lambda_{3} \lambda_{4} \lambda_{5}<0
\end{gathered}
$$

Karena $\lambda_{3}<0$ dan kondisi (12) terpenuhi, maka diperoleh

$$
\lambda_{4} \lambda_{5}>0
$$

Berdasarkan kondisi (11) dan (13) diperoleh

$$
\lambda_{4}+\lambda_{5}<0
$$

Kondisi (12) dan (13) hanya dapat terpenuhi jika dan hanya jika $\lambda_{4}<0$ dan $\lambda_{5}<0$. Dengan demikian, semua nilai eigen dari persamaan karakteristik (8) bernilai negatif, sehingga titik kesetimbangan tanpa penyakit bersifat stabil.

\subsubsection{Analisis Kestabilan Titik Kesetimbangan Endemik}

Untuk memperoleh kestabilan sistem dititik kesetimbangan endemik, substitusi titik kesetimbangan $E_{1}$ pada matriks jacobi (6), sehingga diperoleh :

dengan

$$
J=\left[\begin{array}{ccccc}
A_{11} & 0 & A_{13} & 0 & 0 \\
A_{21} & A_{22} & A_{23} & 0 & 0 \\
A_{31} & A_{32} & A_{33} & A_{34} & 0 \\
0 & 0 & A_{43} & A_{44} & 0 \\
0 & 0 & 0 & A_{54} & A_{55}
\end{array}\right]
$$

$$
\begin{array}{ll}
A_{11}=-\mu-\alpha\left(-\frac{\mu}{\alpha}+\frac{\Lambda(1-\theta)(\delta+\beta \mu)(\mu+\sigma)}{(\delta+\mu)((\mu+\sigma)(\mu+\tau)+(\mu+q \sigma) \omega)}\right), & A_{33}=\frac{\beta(\delta+\mu)((\mu+\sigma)(\mu+\tau)+(\mu+q \sigma) \omega)}{(\delta+\beta \mu)(\mu+\sigma)}-(\mu+\tau+\omega) \\
A_{13}=-\frac{(\delta+\mu)((\mu+\sigma)(\mu+\tau)+(\mu+q \sigma) \omega)}{(\delta+\beta \mu)(\mu+\sigma)}, & A_{34}=(1-q) \sigma \\
A_{21}=\alpha(1-\beta)\left(-\frac{\mu}{\alpha}+\frac{\Lambda(1-\theta)(\delta+\beta \mu)(\mu+\sigma)}{(\delta+\mu)((\mu+\sigma)(\mu+\tau)+(\mu+q \sigma) \omega)}\right), & A_{43}=\omega \\
A_{22}=-\delta-\mu, & A_{44}=-\sigma-\mu \\
A_{23}=\frac{(1-\beta)(\delta+\mu)((\mu+\sigma)(\mu+\tau)+(\mu+q \sigma) \omega)}{(\delta+\beta \mu)(\mu+\sigma)}, & A_{54}=q \sigma \\
A_{31}=\alpha \beta\left(-\frac{\mu}{\alpha}+\frac{\Lambda(1-\theta)(\delta+\beta \mu)(\mu+\sigma)}{(\delta+\mu)((\mu+\sigma)(\mu+\tau)+(\mu+q \sigma) \omega)}\right), & A_{55}=-\mu \\
A_{32}=\delta &
\end{array}
$$

Langkah selanjutnya yaitu mencari persamaan karakteristik diperoleh dari $\operatorname{det}\left(\lambda I-J\left(E_{1}\right)\right)=0$, sehingga diperoleh

$$
\begin{aligned}
& \left(A_{55}-\lambda\right)\left(A_{34} A_{43}\left(A_{11}-\lambda\right)\left(-A_{22}+\lambda\right)\right. \\
& +\left(A_{44}-\lambda\right)\left(\left(-A_{23} A_{32}+\left(A_{22}-\lambda\right)\left(A_{22}-\lambda\right)\left(A_{11}-\lambda\right)\right.\right. \\
& \left.+A_{13}\left(-A_{22} A_{31}+A_{21} A_{32}+A_{31} \lambda\right)\right)=0
\end{aligned}
$$




\section{Rusniwati S. Imran, Resmawan, Novianita Achmad, Agusyarif Rezka Nuha Jurnal Matematika, Statistika E Komputasi}

Berdasarkan persamaan (15) diperoleh lima nilai eigen. Satu nilai eigen diantaranya adalah

$$
\lambda_{1}=A_{55}=-\mu
$$

Karena semua paramater bernilai positif maka $\lambda_{1}<0$, dan untuk keempat nilai eigen lainnya diperoleh dengan menyelesaikan persamaaan berikut

dengan:

$$
a_{0} \lambda^{4}-a_{1} \lambda^{3}-a_{2} \lambda^{2}-a_{3} \lambda+a_{4}=0
$$

$$
\begin{aligned}
& a_{0}=1 \\
& a_{1}=p_{1}-p_{2} \\
& a_{2}=p_{3}-p_{4} \\
& a_{3}=p_{5}-p_{6} \\
& a_{4}=\frac{\Lambda \alpha(1-\theta)(\delta+\beta \mu)(\mu+\sigma)}{\mu}-((\delta+\mu)(\mu+\sigma)(\mu+\tau)+(\mu+q \sigma) \omega)
\end{aligned}
$$

dimana

$$
\begin{aligned}
& p_{1}=(\mu+\sigma)+(\mu+\delta)+(\mu+\tau+\omega)+\frac{\Lambda \alpha(1-\theta)(\delta+\beta \mu)(\mu+\sigma)}{(\delta+\mu)(\mu+\sigma)(\mu+\tau)+(\mu+q \sigma) \omega)} \\
& \begin{aligned}
p_{2}= & \frac{\beta(\delta+\mu)((\mu+\sigma)(\mu+\tau)+(\mu+q \sigma) \omega)}{(\delta+\beta \mu)(\mu+\sigma)} \\
p_{3}=\left(\frac{\Lambda \alpha(1-\theta)(\delta+\beta \mu)(\mu+\sigma)(3 \mu+\delta+\tau+\sigma+\omega)}{(\delta+\mu)(\mu+\sigma)(\mu+\tau)+(\mu+q \sigma) \omega)}\right) & +\left(\frac{\left(\delta^{2}(\mu+\sigma)^{2}+(1-q) \sigma \omega\right)+\left(\beta \mu^{2} \sigma(\omega(1-q)+(\omega+\sigma))\right)}{(\delta+\beta \mu)(\mu+\sigma)}\right) \\
& +\left(\frac{\left(\delta(\mu+\sigma)\left(\sigma^{2}+2 \mu \sigma+(1-\beta)\left(\mu^{2}+\mu \tau+\sigma \tau\right)\right)+\delta \omega\left((1-\beta)\left(\mu^{2}+q \sigma^{2}\right)+2 \mu \sigma\right)\right.}{(\delta+\beta \mu)(\mu+\sigma)}\right)
\end{aligned} \\
& p_{4}=\left(\frac{(\delta \mu \beta \tau(\mu+\sigma))+\left(\delta \omega\left(3 \mu \sigma q \beta+\mu^{2} \beta\right)\right)+\left(\beta \mu^{2}(\omega(\mu+\sigma q)+\tau(\omega+\sigma))\right)}{(\delta+\beta \mu)(\mu+\sigma)}\right) \\
& p_{5}=\frac{(\Lambda \alpha(1-\theta)(\delta+\beta \mu)(\mu+\sigma))\left(\left(3 \mu^{2}+2 \mu(\sigma+\tau+\omega)+\delta(2 \mu+\sigma+\tau+\omega)+\sigma(\tau+q \omega)\right)\right.}{(\delta+\mu)(\mu+\sigma)(\mu+\tau)+(\mu+q \sigma) \omega)} \\
& p_{6}=\frac{(\mu(\delta+\mu))(\delta+\beta(2 \mu+\sigma))((\mu+\sigma)(\mu+\tau)+(\mu+q \sigma) \omega)}{(\delta+\beta \mu)(\mu+\sigma)}
\end{aligned}
$$

Akar-akar karakteristik dari persamaan (16) akan dicari menggunakan kriteria Routh Hurwitz. Berdasarkan kriteria Routh Hurwitz. Persamaan karakteristik (16) memiliki akar-akar karakteristik real negatif atau memiliki bagian real negatif jika dan hanya jika:
i. $\quad a_{0}>0$
ii. $a_{1}>0$ jika $p_{1}>p_{2}$
iii. $a_{2}>0$ jika $p_{3}>p_{4}$
iv. $a_{3}>0$ jika $p_{5}>p_{6}$
v. $a_{4}>0$ jika $R_{0}>1$
vi. $a_{1} a_{2}-a_{0} a_{3}>0$ jika $s_{1}>s_{2}$
vii. $a_{1} a_{2} a_{3}-\left(a_{3}{ }^{2}+a_{3}{ }^{2} a_{4}\right)>0$ jika $s_{3}>s_{4}$

dengan

$$
\begin{aligned}
& s_{1}=p_{1} p_{3}+p_{2} p_{4}+p_{6} \\
& s_{2}=p_{5}+p_{1} p_{4}+p_{2} p_{3} \\
& s_{3}=p_{1} p_{3} p_{5}+p_{1} p_{4} p_{6}+p_{2} p_{3} p_{6}+p_{2} p_{4} p_{5}+2 p_{5} p_{6}+2 p_{1} p_{2} a_{4} \\
& s_{4}=p_{1} p_{3} p_{6}+p_{1} p_{4} p_{5}+p_{2} p_{3} p_{5}+p_{2} p_{4} p_{6}+p_{5}{ }^{2}+p_{6}{ }^{2}+\left(p_{1}{ }^{2}+p_{2}{ }^{2}\right) a_{4}
\end{aligned}
$$




\section{Rusniwati S. Imran, Resmawan, Novianita Achmad, Agusyarif Rezka Nuha Jurnal Matematika, Statistika E Komputasi}

Karena $\lambda_{1}<0$ dan Persamaan karakteristik (16) memiliki akar-akar karakteristik real negatif atau memiliki bagian real negatif, maka semua nilai eigen dari persamaan (8) bernilai negatif yaitu $\lambda_{1}<0, \lambda_{2}<0, \lambda_{3}<0, \lambda_{4}<0$, dan $\lambda_{5}<0$. Sehingga titik kesetimbangan endemik bersifat stabil.

\subsection{Simulasi Model}

Pada bagian ini akan dilakukan simulai terhadap model yang di modifikasi dengan mengggunakn software Phyton 3.7 untuk memperkuat hasil analisis dan menunjukkan kestabilan masing-masing titik kesetimbangan dengan menggunakan nilai-nilai pada Tabel (2). Simulasi numerik digunakan untuk mempelajari hal-hal yang terjadi dalam dinamika populasi penyebaran penyakit pneumonia dengan faktor pengobatan dan imunisasi, serta melakukan variasi nilai parameter, yaitu parameter yang masih memungkinkan untuk dikontrol manusia dalam upaya penekanan penyebaran penyakit pneumonia, diantaranya adalah parameter pengobatan yaitu laju individu terinfeksi yang menjalani pengobatan, dan proporsi keberhasilan pengobatan, serta parameter imunisasi yaitu proporsi imunisasi.

Tabel 2. Nilai Parameter untuk kondisi $R_{0}<1$ dan $R_{0}>1$

\begin{tabular}{|c|c|c|c|}
\hline Parameter & $R_{0}<1$ & $R_{0}>1$ & Sumber \\
\hline$\Lambda$ & 0,8 & 0,8 & Asumsi \\
\hline$\mu$ & 0,4 & 0,3 & Asumsi \\
\hline$\tau$ & 0,3 & 0,3 & {$[5]$} \\
\hline$\alpha$ & 0,5 & 0,98 & Asumsi \\
\hline$\delta$ & 0,91 & 0,91 & {$[5]$} \\
\hline$\beta$ & 0,3 & 0,3 & Asumsi \\
\hline$\theta$ & 0,5 & 0,3 & Asumsi \\
\hline$\omega$ & 0,55 & 0,55 & {$[5]$} \\
\hline$q$ & 0,7 & 0,01 & Asumsi \\
\hline$\sigma$ & 0,91 & 0,91 & {$[5]$} \\
\hline
\end{tabular}

\subsubsection{Dinamika Populasi Untuk $\boldsymbol{R}_{0}<1$}

Dinamika populasi pada kondisi $R_{0}<1$ ditunjukan pada Gambar 2 dengan menggunakan nilai parameter pada Tabel 1 dengan nilai bilangan reproduksi dasar sebesar 0,346253.
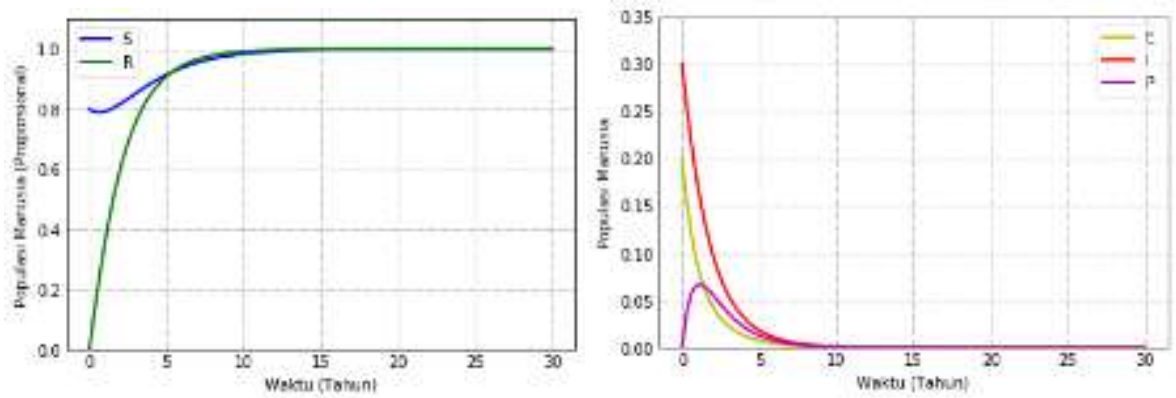

Gambar 2. Dinamika Populasi Untuk $R_{0}<1$ 


\section{Rusniwati S. Imran, Resmawan, Novianita Achmad, Agusyarif Rezka Nuha Jurnal Matematika, Statistika \& Komputasi}

Gambar (2) menunjukkan bahwa masing-masing populasi menuju titik tetap tanpa penyakit atau stabil di sekitar titik tetap tanpa penyakit. Populasi rentan mengalami penurunan jumlah populasi dari nilai awal kemudian mengalami kenaikan jumlah populasi hingga mencapai kondisi stabil di sekitar titik $s=1$. Sedangkan, populasi laten dan populasi infeksi mengalami penurunan jumlah populasi dari nilai awal hingga mencapai kondisi stabil di sekitar titik $e=0, i=0$. Dan untuk populasi pengobatan mengalami peningkatan jumlah populasi dari nilai awal kemudian mengalami penurunan hingga mencapai kondisi stabil disekitar titik $p=0$. Adapun populasi sembuh mengalami peningkatan jumlah populasi dari nilai awal hingga mencapai kondisi stabil di sekitar titik $r=1$.

\subsubsection{Dinamika Populasi Untuk $\boldsymbol{R}_{\mathbf{0}}>1$}

Dinamika populasi pada kondisi $R_{0}>1$ ditunjukan pada Gambar 3 dengan menggunakan nilai parameter pada Tabel 1 dengan nilai bilangan reproduksi dasar sebesar 2,04166.

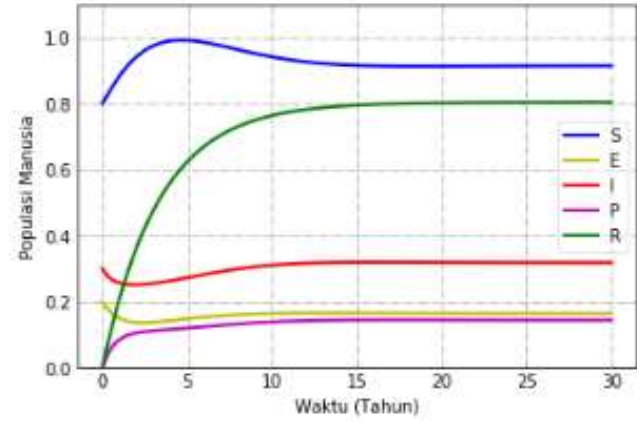

Gambar 3. Dinamika Populasi Untuk $R_{0}>1$

Gambar (3) menunjukkan bahwa masing-masing populasi menuju titik tetap endemik atau stabil di sekitar titik tetap endemik. Populasi rentan mengalami peningkatan jumlah populasi dari nilai awal, kemudian mengalami penurunan jumlah populasi hingga mencapai kondisi stabil di sekitar titik $s=0,914291$ atau sekitar 4571 orang. Sedangkan, populasi laten dan populasi infeksi mengalami penurunan jumlah populasi dari nilai awal, kemudian pada waktu tertentu mengalami peningkatan jumlah populasi hingga mencapai kondisi stabil di sekitar titik $e=$ 0,165288 atau sekitar 661 orang dan $i=0,318874$ atau sekitar 1275 orang. Dan untuk populasi pengobatan mengalami peningkatan jumlah populasi dari nilai awal hingga mencapai kondisi stabil disekitar titik $p=0,144943$ atau sekitar 579 orang. Adapun populasi sembuh mengalami peningkatan jumlah populasi dari nilai awal hingga mencapai kondisi stabil di sekitar titik $r=0,804397$ atau sekitar 3217 orang.

\subsubsection{Simulasi Laju Individu Terinfeksi yang Menjalani Pengobatan}

Pada bagian ini dilakukan simulasi menggunakan nilai-nilai parameter pada Tabel 3 dengan beberapa variasi nilai parameter $\omega$. Simulasi ini bertujuan untuk melihat pengaruh parameter $\omega$ yaitu laju individu terinfeksi yang menjalani pengobatan terhadap penyebaran penyakit pneumonia terhadap nilai $R_{0}$ dan pengaruhnya pada dinamika populasi penyebaran penyakit pneumonia. Adapapun nilai-nilai parameter $\omega$ yang di variasikan dapat dilihat pada Tabel 3. 


\section{Rusniwati S. Imran, Resmawan, Novianita Achmad, Agusyarif Rezka Nuha Jurnal Matematika, Statistika E Komputasi}

Tabel 3. Hasil simulasi parameter $\omega$ terhadap $R_{0}$

\begin{tabular}{|c|c|c|}
\hline Simulasi & $\omega$ & $R_{0}$ \\
\hline 1 & 0,1 & $0,50456<1$ \\
\hline 2 & 0,3 & $0,41935<1$ \\
\hline 3 & 0,5 & $0,35876<1$ \\
\hline 4 & 0,7 & $0,31347<1$ \\
\hline
\end{tabular}

Berdasarkan Tabel 3 dapat dilihat bahwa dengan meningkatkan nilai parameter $\omega$ menyebabkan nilai $R_{0}$ menurun, sehingga upaya yang harus dilakukan untuk menekan laju penyebaran penyakit pneumonia yaitu dengan meningkatkan laju individu terinfeksi yang menjalani pengobatan. Hasil simulasi pengaruh parameter $\omega$ pada dinamika penyebaran penyakit pneumonia dapat dilihat pada Gambar 4.

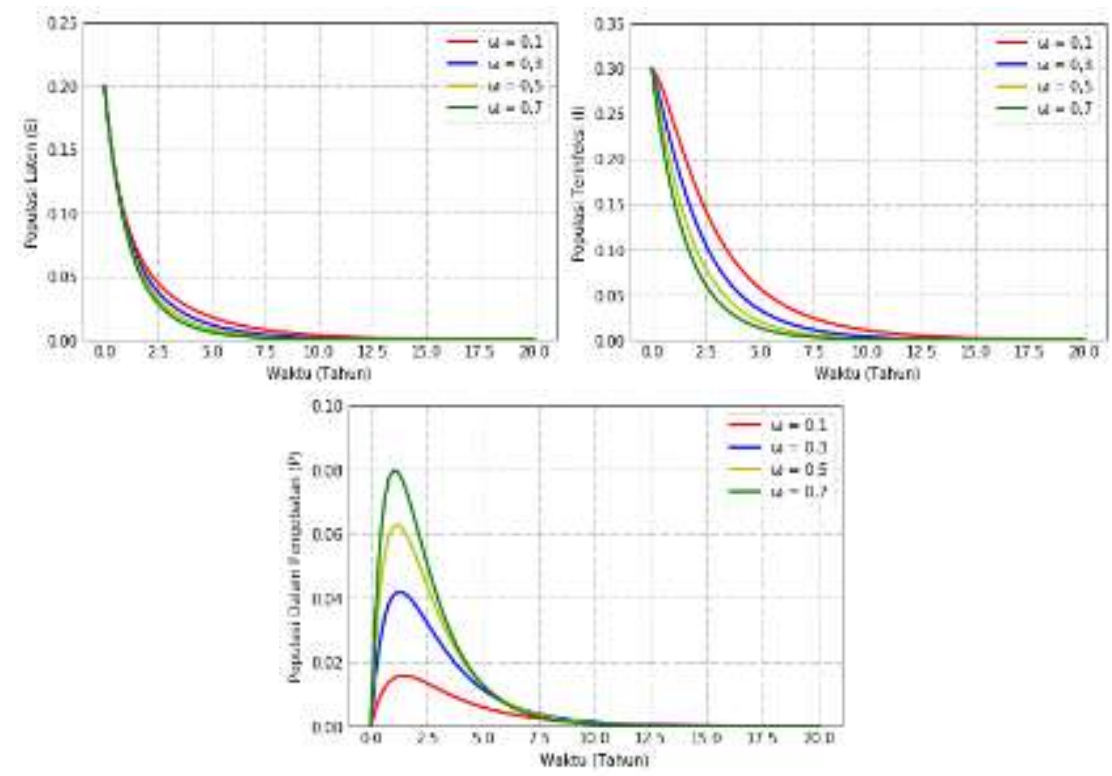

Gambar 4. Simulai laju individu terinfeksi yang menjalani pengobatan

Gambar (4) menunjukkan bahwa pengobatan mempunyai peran yang cukup penting dalam menekan penyebaran penyakit pneumonia yang ditandai dengan adanya jumlah populasi manusia laten dan terinfeksi yang berkurang dari jumlah populasi sebelumnya.

\subsubsection{Simulasi Proporsi Individu Kelas Pengobatan Sembuh}

Pada bagian ini dilakukan simulasi menggunakan nilai-nilai parameter pada Tabel 4 dengan beberapa variasi nilai parameter $q$. Simulasi ini bertujuan untuk melihat pengaruh parameter $q$ yaitu proporsi keberhasilan pengobatan pada individu terinfeksi terhadap penyebaran penyakit pneumonia terhadap nilai $R_{0}$ dan pengaruhnya pada dinamika populasi penyebaran penyakit pneumonia. Adapapun nilai-nilai parameter $q$ yang di variasikan dapat dilihat pada Tabel 4 . 


\section{Rusniwati S. Imran, Resmawan, Novianita Achmad, Agusyarif Rezka Nuha Jurnal Matematika, Statistika E Komputasi}

Tabel 4. Hasil simulasi parameter $q$ terhadap $R_{0}$

\begin{tabular}{|c|c|c|}
\hline Simulasi & $q$ & $R_{0}$ \\
\hline 1 & 0,3 & $0,40011<1$ \\
\hline 2 & 0,5 & $0,37124<1$ \\
\hline 3 & 0,7 & $0,34625<1$ \\
\hline 4 & 0,9 & $0,32442<1$ \\
\hline
\end{tabular}

Berdasarkan Tabel 4 dapat dilihat bahwa dengan meningkatkan nilai parameter $q$ menyebabkan nilai $R_{0}$ menurun, sehingga upaya yang harus dilakukan untuk menekan laju penyebaran penyakit pneumonia yaitu dengan meningkatkan proporsi keberhasilan pengobatan yang diberikan pada individu terinfeksi. Hasil simulasi pengaruh parameter $q$ pada dinamika penyebaran penyakit pneumonia dapat dilihat pada Gambar 5.
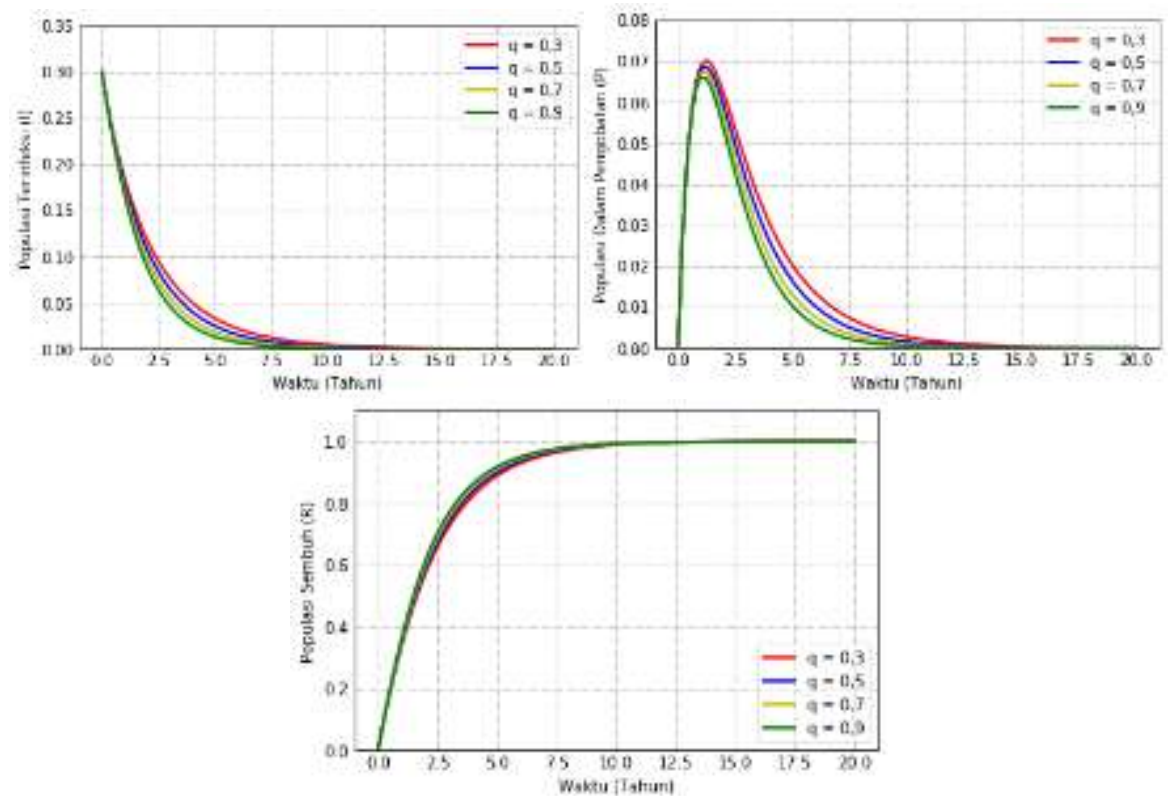

Gambar 5. Simulai proporsi individu kelas pengobatan sembuh

Gambar (5) menunjukkan bahwa proporsi keberhasilan pengobatan mempunyai peran yang cukup penting dalam menekan penyebaran penyakit pneumonia yang ditandai dengan adanya jumlah populasi manusia terinfeksi yang berkurang dari jumlah populasi sebelumnya.

\subsubsection{Simulasi Proporsi Imunisasi}

Pada bagian ini dilakukan simulasi menggunakan nilai-nilai parameter pada Tabel 4 dengan beberapa variasi nilai parameter $\theta$. Simulasi ini bertujuan untuk melihat pengaruh parameter $\theta$ yaitu proporsi imunisasi yang diberikan pada setiap individu yang lahir terhadap nilai $R_{0}$ dan pengaruhnya pada dinamika populasi penyebaran penyakit pneumonia. Adapapun nilai-nilai parameter $\theta$ yang di variasikan dapat dilihat pada Tabel 5 . 


\section{Rusniwati S. Imran, Resmawan, Novianita Achmad, Agusyarif Rezka Nuha Jurnal Matematika, Statistika E Komputasi}

Tabel 5. Hasil simulasi parameter $\theta$ terhadap $R_{0}$

\begin{tabular}{|c|c|c|}
\hline Simulasi & $\theta$ & $R_{0}$ \\
\hline 1 & 0,5 & $0,24182<1$ \\
\hline 2 & 0,52 & $0,23215<1$ \\
\hline 3 & 0,54 & $0,22248<1$ \\
\hline 4 & 0,56 & $0,21280<1$ \\
\hline
\end{tabular}

Berdasarkan Tabel 5 dapat dilihat bahwa dengan meningkatkan nilai parameter $\theta$ menyebabkan nilai $R_{0}$ menurun, sehingga upaya yang harus dilakukan untuk menekan laju penyebaran penyakit pneumonia yaitu dengan meningkatkan proporsi imunisasi yang diberikan pada setiap individu yang lahir. Hasil simulasi pengaruh parameter $\theta$ pada dinamika penyebaran penyakit pneumonia dapat dilihat pada Gambar 6.
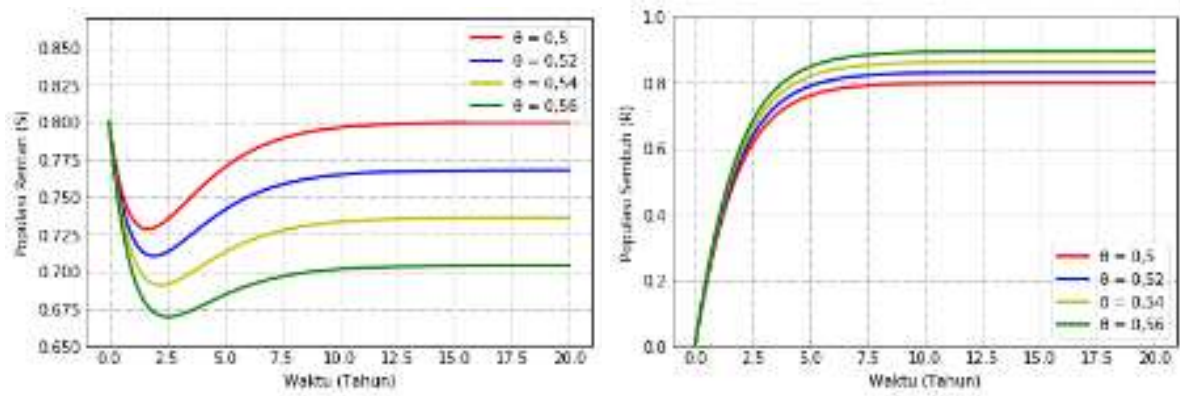

Gambar 6. Simulai proporsi imunisasi

Gambar (6) menunjukkan bahwa penyebaran penyakit pneumonia dapat berkurang dengan adanya imunisasi pada setiap individu yang lahir, hal tersebut ditandai dengan adanya jumlah populasi rentan yang berkurang, serta jumlah populasi sembuh meningkat. Dengan demikian tingkat imunisasi memiliki peran yang cukup penting dalam menekan penyebaran penyakit pneumonia.

\section{Kesimpulan}

Model SEIPR pada penyebaran penyakit pneumonia pada balita dengan faktor imunisasi dan pengobatan memiliki dua titik kesetimbangan yaitu titik kesetimbangan tanpa penyakit dan titik kesetimbangan endemik. Titik kesetimbangan tanpa penyakit mencapai kondisi stabil pada saat $R_{0}<1$ yang menunjukkan bahwa dalam jangka waktu tertentu penyakit akan menghilang dari populasi, sedangkan titik kesetimbangan endemic mencapai kondisi stabil pada saat $R_{0}>1$ yang menunjukkan bahwa penyakit akan tetap menyebar dalam populasi. Hasil simulasi menunjukkan bahwa peningkatan nilai laju individu terinfeksi menjalani pengobatan, tingkat keberhasilan pengobatan, dan proporsi imunisasi dapat menekan angka bilangan reproduksi dasar $\left(R_{0}\right)$ sehingga penyebaran penyakit dalam populasi dapat dikendalikan.

\section{DAFTAR PUSTAKA}

[1]. Ault, J.C \& Ayres, Frank. (1999). Persamaan Diferensial dalam satuan SI Metric. Erlangga, Jakarta. 


\section{Rusniwati S. Imran, Resmawan, Novianita Achmad, Agusyarif Rezka Nuha Jurnal Matematika, Statistika E Komputasi}

[2]. Dinkes Surabaya. Infeksi Saluran Pernafasan Akut dan Pneumonia Pada Anak, (2013). URL http://dinkes.surabaya.go.id. [17 Desember 2019]

[3]. Driessche, P. \& Watmough, J. 2002. Reproduction Number and Subtreshold Endemic Equilibrium for Compartmental off Disease Transmission. Mathematical Biosciences, 180:29-48.

[4]. Fajar, R., Sari, M., Kurniastuti, I., \& I., L. (2016). Analisis Kestabilan Model Matematika Penyebaran Infeksi Penyakit SARS dengan Faktor Host dan Vaksinasi. Seminar Nasional Matematika dan Pendidikan Matematika UNY.

[5]. Fajariyah, N. I., Sukestiyarno, Y. L., \& Junaedi, I. (2018). Pemodelan Matematika Penyebaran Penyakit Tuberkulosis Dengan Strategi DOTS. UNNES Journal of Mathematics, Vol. 7, No. 2, 136-137.

[6]. Jacob, O., Joseph, M., \& Paul, O. (2013). Mathematical Model for Pneumonia Dynamics with Carriers. Journal of Math, Vol. 7, No. 50, 2457-2473.

[7]. Kemenkes RI. (2017). Data dan Informasi ProfilKesehatan Indonesia 2017. Kementerian Kesehatan Republik Indonesia, Jakarta.

[8]. Kaneshiro, N. K. \& Zieve, D. Pneumonia - Children - Community Acquired, 2016. URL https://medlineplus.gov/ency/article/007690.htm. [17 Desember 2019]

[9]. Mbabazi, F. K., Mugisha, J. Y. T., \& Kimathi, M. (2020). Global Stability of Pneumococcal Pneumonia with Awareness and Saturated Treatment. Journal of Applied Mathematics, 2020, 1-12. https://doi.org/10.1155/2020/3243957

[10]. Ndii, M. Z. P. (2018). Pemodelan Matematika. CV Budi Utama, Yogyakarta.

[11]. Otoo, D., Opoku, P., Charles, S., \& Kingsley, A. P. (2020). Deterministic epidemic model for $\left(S V C_{S y} C_{A s y} I R\right)$ pneumonia dynamics, with vaccination and temporal immunity. Infectious Disease Modelling, 5, 42-60. https://doi.org/10.1016/j.idm.2019.11.001

[12]. Rahman, K. S., Mitkari, S. R., \& Shaikh, S. (2020). Modeling the Impact of Vaccination, Screening, Treatment on the Dynamics of Pneumonia. Journal of Scientific Research, 12(4), 525-536. https://doi.org/10.3329/jsr.v12i4.45815

[13]. Rahmawati, H., Widowati, \& Kartono. (2015). Analisa Kestabilan Model Matematika Penyakit Pneumonia Dengan Carriers. Jurnal Matematika, 4(2).

[14]. Resmawan, R., \& Nurwan, N. (2017). Konstruksi Bilangan Reproduksi Dasar pada Model Epidemik SEIRS-SEI Penyebaran Malaria dengan Vaksinasi dan Pengobatan. Jurnal Matematika Integratif, 13(2), 105. https://doi.org/10.24198/jmi.v13.n2.12332.105-114. 


\section{Rusniwati S. Imran, Resmawan, Novianita Achmad, Agusyarif Rezka Nuha Jurnal Matematika, Statistika E Komputasi}

[15]. Resmawan, R., \& Yahya, L. (2020). Sensitivity Analysis of Mathematical Model of Coronavirus Disease (COVID-19) Transmission. CAUCHY, 6(2), 91-99. https://doi.org/10.18860/ca.v6i2.9165

[16]. Riskesdas. Badan Penelitian dan Pengembangan Kesehatan Kementerian RI. (2018). URL http://www.depkes.go.id/resources/download/info-terkini/hasil-riskesdas-2018.pdf. [17 Desember 2019]

[17]. Setiati, S., Alwi, I., Sudoyo, A., Simadibrata, M., Setiyohadi, B., \& Syam, A. (2015). Buku Ajar Ilmu Penyakit Dalam. Interna Publishing, Jakarta Pusat.

[18]. Susanti, N. D. (2016). Analisis Perhitungan Bilangan Reproduksi Dasar (R0) pada Model Matematika Dinamika Malaria Host-Vector. Skripsi, Universitas Islam Negeri Maulana Malik Ibrahim Malang.

[19]. Tu, P. (1994). Dyamical System: An Introduction with Applications in Economics and Biology. Springer-Verlag, New York.

[20]. WHO. Pneumonia. (2016). URL http://www.who.int/news-room/factsheets/detail/pneumon ia [17 Desember 2019] 